\title{
Some aspects of the sociology of information: a framework for analysis of information provision in the resource centre sector of South Africa
}

\author{
C-M. Karelse* \\ INFOLIT, 14 Greenwich Grove, Station Road, Rondebosch, 7700 Republic of South Africa \\ cmk@grove.uct.ac.za \\ M.C. Nassimbeni \\ School of Librarianship, University of Cape Town, Private Bag, Rondebosch, 7700 Republic of South Africa \\ mcn@education.uct.ac.za
}

\begin{abstract}
The purpose of this article is to explore aspects of the sociology of information in an attempt to construct a conceptual framework as a tool for understanding alternative information provision in the progressive resource centre sector of South Africa. The point of departure is that the approach to information provision in this sector has been different from that in traditional libraries. It is argued that aspects of the sociology of information are germane to an understanding of the different approaches. Consequently, the link between information, consciousness and ideology; and the relationship between information, education and development are considered. The article draws on a number of theorists whose foundational works on information are useful in the task of constructing the conceptual framework. Thus, for example, the article draws on contributions by Dervin, Althusser and Gramsci for their insights into the situationality of information, ideological control of information and hegemony, respectively. Reflecting on the pattern of information provision in the past, and looking forward to the role of information providers in reconstruction and development, the article argues that the integration of information, education and development is important for the realization of life-long and resource-based learning.
\end{abstract}

Sekere aspekte van inligtingsosiologie word bespreek met die doel om 'n konseptuele raamwerk saam te stel om die lewering van inligtingdienste aan die alternatiewe inligtingsektor in Suid-Afrika beter te kan verstaan. Die vertrekpunt is dat die verskil tussen hierdie sektor van die inligtinginfrastruktuur en die tradisionele biblioteeksektor beter verstaan kan word deur ' $\mathrm{n}$ studie van inligtingsosiologie. Dus word die verband tussen inligting, bewussyn en ideologie ondersoek, asook die verband tussen inligting, opvoedkunde en ontwikkeling. Die artikel verwys na die belangrike bydrae van teoretici soos Dervin, Althusser en Gramsci vir insigte met betrekking tot die omstandighede van inligting, die ideologiese beheer van inligting, en hegemonie. Daar word geargumenteer dat die integrasie van inligting, opvoedkunde en ontwikkeling noodsaaklik is vir die nuwe benadering tot voortgesette leer.

*Author to whom correspondence should be addressed.

This article proposes a conceptual framework to describe and analyse South Africa's legacy of information deprivation and control which in turn provides a context within which to view the history of the emergence of the alternative resource centre movement. The framework was developed as part of a research project undertaken by Karelse (1995) to investigate the contribution made by two alternative service or nongovernmental organizations (NGOs) to the provision and delivery of information in South Africa. The research resulted in the award of the MBibl degree by the University of Cape Town at the end of 1995. The article explores some aspects of the sociology of information: the link between information, consciousness and ideology; and the relationship between information, education and development. This conceptual framework can be used to understand the milieu of service organizations, and the ways in which information and education-based programmes intervene to transform socioeconomic conditions. The related issues of the production of meaning and the construction of knowledge are debated since they enrich the discussion of how people assimilate and impart information and the role of ideology in the control of the flow of information.
The framework was used to theorize the practice of information provision in two progressive service organizations and forms part of a body of research into the resource centre movement which has engaged the attention of a number of analysts (cf. for example Stilwell, 1992; Karlsson, 1994). Karlsson has noted that resource centre workers perceived their own need to conceptualize, define and differentiate resource centres from other types of information services. They recognized that their type of service was significant - historically and conceptually - and this needed to be articulated and understood (Karlsson, 1994:2). Karelse's thesis showed how Merrett's argument (1995:11) that

'the key to understanding the circumstances in which

LIWO (Library and Information Workers Organiza-

tion) developed ... is contained in the concept "hegemony"”

could equally be applied to the progressive resource centre movement.

\section{Seeking a conceptual understanding of information}

Information permeates all levels of society and is transmitted by numerous agencies through a wide range of channels. As Fairthorne (1967:710) notes, the term is used for an 
amorphous mass of ill-defined different activities and phenomena. Miles (1990:8) further argues that 'all human labour involves information-processing; and ... all commodities produced by the economy embody and provide information'. These claims suggest that it may be near impossible to define information in precise terms. An understanding of the role it assumes in social contexts will enable greater insight into the importance of information in a developmental setting such as South Africa's.

\section{Information and knowledge}

In attempting to understand the nature of information, theorists have tended to link information to knowledge. Brookes argues that knowledge is a summation of many bits of information which have been organized into some sort of coherent entity (1975:48). Wersig (Smith, 1982:75) on the other hand, points out that since knowledge is always in a state of flux it is near impossible to determine a state of knowledge and on this basis, dismisses Brookes' concept of information. He argues instead, as do Yovits and Whittemore (1973:222), that information reduces uncertainty, a quality which constitutes its definitiveness. Although Wersig's point of contention that knowledge is in a constant state of flux is valid, there is no doubt that information does have a direct relationship with knowledge and impacts upon people's knowledge bases.

While these arguments contribute to the conceptualizing of information and drawing an associational relationship with knowledge, the debates have occurred within the framework of strengthening or moulding what Dervin (1977:19) calls a normative view of information. The core assumption of this view is that information exists independently of human action and that its value lies in describing reality and therefore in reducing uncertainty about reality. This means that conceptualization has sometimes occurred in isolation of a broader, more holistic understanding of the sociology of information.

\section{Situationality of information}

The debate about a conceptual understanding of information has been significantly enriched through recent developments in the field of information science. These developments signal a paradigm shift through which a more advanced conceptualization of the nature of information is being uncovered. Dervin and Nilan (1986) document aspects of the shift noting changes in approaches to and ways of viewing information, information need and users. They explain that the traditional, normative paradigm views information as objective, 'as something that has constant meaning and some element of absolute correspondence to reality', while what they call the 'alternative' paradigm, 'posits information as something constructed by human beings' (1986: 16). In the latter view, information only assumes value and significance in its application to a social setting. Hence Belkin's (1977) view of information as that which is capable of transforming image structures falls within this paradigm. The alternative approach then would speak of the situationality of information: the fact that information needs are generated in and thus linked to situational contexts.

King and Palmour (1980:68) remark that we often tend to think of information in terms of information products and services rather than the information conveyed or the use that is made of it. In developing this idea of the use-value of information, they comment that information must constitute information to the user since

'messages may be information to one person but not another because of language barriers or lack of interest or understanding, such as with mathematical symbols or chemical compounds' (1988:68).

Furthermore King and Palmour (1980: 79) argue that the use of information is a means to the end and not the end in itself. The value is derived from the many ultimate consequences of information use. This underscores the point that information assumes importance only in relation to the demand for it. It ought not to be assumed that information has value in its own right (Dervin, 1977:25). In other words, information is not an end in itself but, when appropriate, merely a means towards improving and/or transforming environments of use and the consciousness of users.

Childers and Post (1975:35) seem trapped in the notion of information being valuable irrespective of the need for it. They argue that the disadvantaged individual needs large remedial doses of information to bring him up to "information par" with the rest of society'. While information impoverishment and misinformation are features of all stratified societies in which there are relations of domination and power struggles, information inequality is not a quantitative but a qualitative social issue. Information inequality is not something which can only be redressed by 'equating' the level of information provision to bring impoverished groups up to par with more privileged sectors. This unlocking and redistribution of resources would certainly constitute a meaningful, although superficial measure to correct imbalances. Rather, the fundamental issues of who controls and produces information; the use-value of the information; the way in which delivery occurs as well as the interests this serves; and the type and format of the information being made available, will have to be addressed in resolving the problem of information imbalances and the development of appropriate information services.

Implicit in the above argument is the fact that people not only seek and assimilate information, they also create or produce information (King \& Palmour, 1980:68; Dervin, 1977:21). This assertion has interesting implications for those active in the information sphere: given that information derives use-value from its adoption by an individual in a particular situation, and given that information means different things to different people, it follows that information is acquired and assimilated in different ways. The fact that people create information means that the information environment is not a closed system, but one which is constantly developing and changing. 
Dervin (1977:22) best expounds this dynamic information environment idea. She proposes that a distinction be made between 'objective' and 'subjective' information. The former 'describes reality, the innate structure or pattern of reality'; the latter is 'defined as ideas, the structures or pictures imputed to reality by people'. This distinction supports the view that information is assimilated in different ways by different people and further underlines the fact that 'information can be whatever an individual finds informing'. Hence information becomes situational and not merely 'objective' as is the commonly held view. This model, says Dervin, "moves our attention away from "objective" information, toward assessing the "cognitive maps or pictures" of an individual'.

In Dervin's model, 'objective information' is called information1, and 'refers to external reality'; 'subjective information' is called information 2 and 'refers to internal reality' She argues that information 1 and information 2 are linked by an individual through some kinds of behaviour which are in themselves legitimate informational inputs: information3 (Dervin, 1997:22).

The difficulty with Dervin's concept of 'objective, external' reality is: to what extent and from what vantage point is any reality 'objective' and 'external'. By virtue of the articulation between information 1 and information2, individuals interface with society, with what Dervin calls external reality. Thus they are not merely passive subjects in the context of a larger picture in which external realities are static. Their subjectivity is always balanced or counter-balanced by their agency or their capacity to impact upon and transform realities which are thus constantly changing. Agency assumes greater or lesser significance in different contexts since it is influenced by a wide range of variables: audience, voice, power, available channels, and group dynamic, to mention but a few. The point is that while Dervin helps us distinguish between different types of information, we cannot lose sight of the subtle nature of information or of a situational and contextual understanding of information which she herself emphasizes. The terminological difficulty with her model is that at the same time as challenging the notion of 'objective information' as espoused in the traditional paradigm, Dervin uses the very concept to denote a particular kind of information. This leads to confusion and begs the question: what, indeed, constitutes 'objective' information? This issue is addressed in greater detail in the following discussion of the relationship between information and ideology.

\section{Information and ideology}

The link between information and ideology is explored here as a means of understanding the prominence and indeed the value which information assumes in the context of power struggles. The intention here is not to discuss the relation between ideology and other social structures such as the political and economic spheres. Rather, it is to probe the issue of the situationality of information which an understanding of ideology deepens, and is framed by a systems rather than a mechanical or deterministic approach. It is instructive to consider the writings of Althusser (1972) and Gramsci (1977; 1985) whose foundational works on ideology and the role of information in social formations have informed theories of how information has been used to advance both relations of power by dominant social groupings and the struggles of the oppressed in efforts to overthrow repressive power relations.

\section{Althusser's contribution}

The Contemporary Cultural Studies Unit (CCSU) established at the University of Natal to address issues of popular culture, explains that the concept of ideology, although in the lexicon since the French ideologues of the eighteenth century, came into greater use after the First World War to explain 'how both the immanent laws of development as well as the revolutionary potential of the workers came to be neutralized' through capitalist control (Contemporary Cultural Studies Unit, 1988: 16). Althusser argued that consciousness (ways of seeing, interpreting and understanding reality) arise in ideological state apparatuses (ISAs), such as the family, schools, media and the church, and is perpetuated or reinforced by their practices thus reproducing a society's dominant social relations. ISAs function alongside repressive state apparatuses (RSAs), such as the police and courts to reproduce social systems.

Althusser's contention was that individuals are socialized through the ISAs and RSAs to assume particular 'divided' roles expressed in a series of 'I's', to occupy places in a series of social relationships. He highlighted the prominent role in a technologically advanced society of the media in 'ideological regulation, and (how they) repeatedly signify, and thereby naturalise, the social relations embedded in ideology' (Contemporary Cultural Studies Unit, 1988:17). The media play the role of unifying the 'variety of ideological I's under the sign of an over-arching will or identity' (1988:19). A crucial concern with Althusser's contribution arises from his intimation that persons are mere passive subjects in their social contexts raising the question of the extent to which individuals have agency to challenge their socialization. Culturalists take issue with Althusser on this aspect of his work. They argue that while there may exist a dominant cultural logic in any given society, 'any dominant form elicits alternative forms (and that) resistance is the principle of historical change' (1988:20-21). Essentially, they argue for individual capacity and agency as a key impetus in mobilizing historical change.

While Althusser's reproduction theory has been extensively analysed, his comment on ISAs together with the culturalist critique, provides a basis on which to view other contributions regarding information generating institutions and knowledge-power relationships. Therborn's (1980:85) reservations concerning Althusser's ISAs are worth noting, for they provide us with a deeper understanding of the ideological terrain. He argues that ideologies do not only exist in institutionalized apparatuses and contends that the family, for instance, is not ordinarily a state apparatus. Fúrthermore, he argues that it 'seems rather sterile and even actively 
confusing, from an analytical point of view, to extend the concept of the state to cover everything that serves the reproduction of a social order'. Ideological apparatuses should instead be viewed as 'part of the organization of power in society, and the social relations of power are condensed and crystallised within the state'. A significant concept which he introduces to explain the nuanced nature of ideological processes is identifying the role of 'counter-apparatuses' such as mass organizations and alternative formations which influence the way people are made to see, interpret and shape their realities.

\section{Dominant and counter ideologies}

The discussion thus far raises the question of the relative power of dominant ideologies in relation to counter ideologies. Jansen (1991:19) argues that the "central feature of knowledge-power relationships in the world system is one of domination by the core over the periphery'. He goes on to argue that while the (apparent) hegemony of the Western world is challenged both within the core and vehemently resisted from within the periphery, he is emphatic that

'the notion of dependency still remains a powerful means of explaining the heavy, continued and uncritical reliance on theories and methods originating from the Western core. Third world intellectuals and their research endeavours are often heavily influenced and constrained by imported theoretical orientations which do not fit their local contexts or capture the cultural-specific nuances of situations in which they work' (1991:20).

This postulation has to be considered in relation to a number of factors. The unique and sometimes prolific work which is fairly well established within the NGO sector not only challenges dominant ideology but assumes a semi-autonomous dynamic. Counter methods are not only significant in relation to mainstream thought, but are rooted in popular experience and stimulate alternative thinking in accordance with their own unfolding dynamic. Put simply, counter methodology is not only reactive by nature but develops a dynamic of its own. The work performed by certain intellectuals - organic and otherwise - signify self-sustaining breakaways from traditional and dominant views. The culturalists point out that ideology and cultural forms are in a constant state of shifting impermanence and argue that relations are not as categorical but more nuanced than the core-periphery model suggests (Contemporary Cultural Studies Unit, 1988:20).

Thus the notion that knowledge and ideology are constantly in flux, and that there are on-going battles which challenge dominant power relations means that counter apparatuses such as service organizations which constitute an extragovernmental political force contribute to shaping the ideological terrain. As Lee (1994:35) characterizes them,

'NGOs are one element of civil society which, as a whole, is an autonomous entity outside of the family, that is accorded an important and constraining role with respect to the state and political power-holders. In other words, NGOs are one of the sets of organizations which limit the power of the state in relation to the lives of the citizens, and mediate between individuals and the state'.

However this does not refute the views expressed by Jansen (1991) and by Mattelart (1980) in the paragraph below, namely that dominant groupings wield extraordinary power in presenting their systems as 'correct'.

Mattelart (1980:36-47), writing about the Chilean experience, argues within Althusser's structuralist framework that the mass media are ISAs which serve to reproduce particular social formations, that the press functions in the interests of the owners of the means of production; that taking over the organs of power to serve different interests calls for their fundamental transformation not a mere control of the apparatuses; and that the dominated (what he calls the 'left') 'are victims of a congenital deformation, born as they were within a frame of reference structured by the bourgeois ideology of domination'. His contention is that dominant classes entrench power not only through the content of messages but the very organization of the institutions which propagate their ideology and that their socialization of subjects is more deeply rooted than it appears. This argument ties up with Jansen's dependency theory referred to above. In the South African experience the apartheid state used various apparatuses including the mass media, public libraries, and school text books to maintain their hegemony.

\section{Gramsci's contribution}

Gramsci (1977;1985) developed Lenin's concept of hegemony to explain that dominant classes maintain their positions of power by winning the consent of the masses. In discussing the concept of hegemony, Gramsci's comments on the intellectuals, ideology and the 'war of position', all of which have bearing on the sociology of information, will be considered.

Gramsci's theory can be summarized to encapsulate the following main propositions:

- Any comment on hegemony necessarily entails, whether implicitly or explicitly, a comment on a fundamental class (such as a capitalist or working class) since it is these groupings which attempt to achieve hegemony.

- Hegemony would refer to the 'control' or leadership which a class is able to exercise over other classes and/or social groups in an alliance with them through the development of a historic bloc.

- A historic bloc refers to the entire array of institutions the sense-giving institutions such as religious, artistic and legal ones - which give people consciousness (Contemporary Cultural Studies Unit, 1988:24). Within a historic bloc, Gramsci (1977:377) writes,

'material forms are the content and ideologies are the form (though) the material forces would be inconceivable historically without form and ideologies 
would be individual fancies without the material forces'.

- Gramsci sees change as a continuous process, not simply as an eradication of the old order but as a continuous development and building of the new order which involves winning the consent of the masses.

To achieve hegemony initially, the working class has to win the active consent of other classes and has to appear capable of leading in place of the dominant or ruling class. As Gramsci (1977:80) writes in the Prison Notebooks,

'the normal exercise of hegemony on the now classical terrain of the parliamentary regime is characterised by the combination of force and consent. Indeed, the attempt is always made to ensure that force will appear to be based on the consent of the majority, expressed by the so-called organs of public opinion newspaper and associations - which, therefore, in certain situations, are artificially multiplied'.

Gramsci differentiates between traditional and organic intellectuals and their roles in building the hegemony. Organic intellectuals of the proletariat do not have to be of working class origin, but they are those agents who represent the interests of this class. Traditional intellectuals are 'freefloating' intellectuals who ostensibly assume an independence from class association although in practice, Gramsci argues, they serve the interests of the dominant class. Since it is the role of the organic intellectuals and more correctly of the revolutionary party - the collective intellectual - to build the hegemony of that class, it is their duty to undermine the traditional intellectuals. As Simon (1982:95) argues,

'one of the most important characteristics of any rising class is its struggle to assimilate and conquer ideologically the traditional intellectuals'.

It follows then that the working class has to develop a stratum of organic intellectuals to bring about hegemonic change. The contribution of 'activists' in service organizations can be partly understood in this light.

Gramsci (1977) draws a distinction between historically organic, necessary ideologies and arbitrary nationalistic ones. The former 'organize human masses and create the terrain on which men [sic] move, acquire consciousness of their position, struggle etc'. The latter 'only create individual movements, polemics and so on' (1977:377). These definitions and distinctions are important since they move beyond the narrow notion of 'false consciousness' to show that working class hegemony must be developed prior to the seizure of state power. Ideology is propagated through the institutions and organizations of civil society or private society - the sphere of the integral state which Gramsci contrasts with the repressive/ coercive state which exerts direct domination and in which popular democratic struggles occur. Gramsci often refers to the integral state which includes both civil society and the state as 'hegemony protected by the armour of coercion' (1977:263) and points out that civil society has a definite political character for it is here that the struggle for hegemony is waged.
Gramsci argues that there is often a contradiction between one's socialized beliefs and one's actions, implying that the roots of revolutionary ideology are repressed by the dominant ideology until the latter is transformed by the former. A hegemonic class in ideological struggle never completely demolishes the existing ideology/collective will. Instead, the process is dialectical whereby the positive features, usually subordinate in the existing ideological formation, are transformed and articulate with developing ideologies in becoming incorporated into the new collective will. The 'struggle for hegemony consists of this process of disarticulation-rearticulation' (Mouffe, 1980:175). Furthermore, to achieve a new collective will, groups have to undergo moral and intellectual transformation. This is the process of ideological struggle in which the working class, by transcending its 'corporate' consciousness, is able to combine the interests of other classes and social groups with its own and act as the leadership of this social bloc, that is it develops a political consciousness and becomes hegemonic. This process of ideological struggle is one in which the working class challenges ruling class/bourgeois hegemony which gives rise to a crisis for ruling class leadership in which case the latter resorts to a passive revolution in an attempt to reorganize and re-establish its hegemony (Buci-Glucksmann, 1980:54-6).

During the process of moral and intellectual reform - by which a common conception of the world will be created - or the development of a new historic bloc, ideology acts as 'cement' in the cohesion of diverse classes and social groups who share a common aim. On a practical level this would require the assimilation of popular democratic struggles which do not necessarily have a class character/base - with those of the working class. As has been previously mentioned, a class becomes hegemonic not through imposing its interests on other classes and social groups but through combining the interests of other social groups with its own so that a new ideological formation develops. Fundamental to this process is the articulation between the old ideological formation and the arising one so that a new ideological formation encompassing certain popular elements of the old bourgeois formation is developed.

Ideological struggle occurs within the development of a war of position in which the working class continually challenges bourgeois hegemony and fights not only to achieve hegemony but also to maintain it. The working class within its broad democratic alliance, constantly tries to undermine the legitimacy of the bourgeoisie throughout civil society. So as to break bourgeois rule, the working class has to try to sever the relations of consent fundamental to bourgeois rule. This is a dialectical process involving resistance, repression and counter-resistance in a constant attempt to isolate the bourgeois minority from the rest of society, namely the masses under working class leadership.

Although Gramsci's contribution is couched in the rhetoric of class analysis and struggle, it provides insight into how processes of fundamental transformation occur through struggles occurring at the levels of the sense-giving institutions 
(religious, cultural, legal etc.) (Contemporary Cultural Studies Unit, 1988:24). Gramsci's writing allows for an understanding of how institutions such as library and information services constitute part of the terrain in which dominant groupings propagate their ideology while resistant or revolutionary groupings challenge, assert and disseminate alternative views and symbols.

The contributions of these authors, writing at a time of social change, highlight the importance of information transmitted through material forms such as the mass media, public institutions and language - in reproducing and/or transforming the status quo. A theme which comes through is that ideologies are constantly in flux, they never remain static but are always in motion, indicating the nuanced nature of social change.

\section{Information and control}

It is evident that ruling groups which have achieved hegemony dominate the ideological terrain to create the impression that the status quo is a natural and acceptable way of life. As Wyley (1990:7) writes:

'Ideological regulation operating in the interests of a hegemonic alliance relies on control of the ways in which meaning is produced in society, and the constant repetition and reinforcement of such controlled meaning, with the eventual result that the dominance of ruling groups, or the status quo, is presented as natural'.

In this way subjects are socialized to perceive and accept a dominant portrayal of reality as fashioned by ruling groups. But this argument easily results in what could be a simplistic notion of 'false consciousness', implying that this is the only reality subjects perceive. As with knowledge, reality is not static but is in constant formation just as knowledge is in constant flux. It is fluid and constructed by individuals in accordance with the articulation between their internal and external worlds. This ties up both with Dervin's information1 and 2 model.

The concept of multiple realities which is premised on the belief that there is not an absolute, objective reality, is further complicated by the fact that we use language and symbols which have their own constraints, to communicate our meanings. We are thus often unable to articulate our experience of reality in exact terms, and communicate instead a representation of that reality.

Notwithstanding this problem of communicating experiences and different realities, it can generally be argued that one of the ways in which the dominant groups assert their power is through employing the notion of objectivity and neutrality. These notions are particularly immanent in the field of journalism with some journalists claiming to be objective or neutral in their accounts of news. As will be discussed below, these claims are undermined by the fact that '... we are all bound by our cultural base, our class positions and our political bias' (Contemporary Cultural Studies Unit, 1988:15)
The mass media are one of the important institutions used to reproduce social systems. As the CCSU (1988:27) state:

'We can see that the media serve as a strategic weapon in the battle to win our hearts and minds to the cause of business, industry and capitalist society

... The media serve to reinforce the world view on which the dominant cultures are based'

Harris (1986:215) notes that it is not only the mass media which perform a reinforcing role in society $v i s$-à-vis the reproduction of dominant socio-political, economic and cultural relations. He states that "libraries like the media were seen to be largely reflective or expressive of the achieved consensus' and he draws on Stuart Hall to argue that 'since the consensus was a "good thing", those reinforcing efforts ... were given a benign and positive reading'. He further writes that:

'Librarians were seen as apolitical servants of the "people" and were expected to be completely neutral on social, economic and political questions - a passive "mirror" of societal interests and values. Libraries came to be seen as simple mirrors, neutral reflections of society's racial memory' (1986:255).

Similarly to the mass media, the public library system in the apartheid years was also used to entrench dominant ideology by virtue of the collections they held, their geographical concentration in predominantly 'white', urban areas and their concomitant inaccessibility to the vast majority of the citizenry. Where located in historically black areas, they often failed to provide an appropriate educational or developmental role. As a recent report notes:

'There has been, and still is, inequitable distribution of facilities. It is clear that the deracialisation of libraries (for example the scrapping of the Separate Amenities Act) has not in itself brought about a more equitable system, particularly if one looks at the physical location of school and public libraries (National Education Policy Investigation, 1992:43).

With regard to the role of librarian, as Wyley (1990:10) notes in writing about apartheid South Africa,

'Librarians in South Africa ... are faced with involvement in the implementation of restrictions on academic and intellectual freedom ... in practice librarians are forced to act as agents of those seeking ideological regulation of South African society ... compelled by law to act as agents of the state, or collaborators of the system ... librarians accept and facilitate censorship'.

This clearly is a generalization to which there were exceptions. However, the point being asserted is that, in accordance with Harris' earlier claims, the work of librarians served to reproduce rather than challenge the status quo.

It is clear then that embedded in the role which the media and other information institutions such as libraries play in the production of meaning and the reproduction of systems, are the issues of objectivity and censorship. The notion of objectivity is linked to the positivist concept of neutrality and is 
often promoted by ruling groups controlling the media to create the impression that reports depict reality as the 'only' or 'absolute' way in which it exists. Questions of partiality or subjectivity on the part of journalists are dismissed as unprofessional and an objectivist framework is projected as a canon of the media. This view has been challenged by numerous authorities such as the CCSU (1988:15) who reject the idea that the news simply consists of facts and argue that within journalism there is a complex process of selection and interpretation that ultimately produces 'the news'. The selection process is also affected by a range of factors, beginning with the straightforward limitations of time, resources and accessibility.

Mattelart (1980:38) argues that journalists, as with all individuals, operate within the frame and terms of reference of their social group. Their selection criteria are determined by their allegiances and values. He says: 'objectivity is the consecration of an ideology and class interest as a universal value'. Objectivism also holds that external reality is factual and that journalism merely describes or presents these facts. However

"any description of reality "as it is" is in fact imbued with ideological meaning ... interpretation is ... implicit in the very selection itself ... the interpretive grid encodes the transmitted events in terms of the dominant system of values'.

This relates to Dervin's information 1, 2 and 3 model in which she proposes that external reality could be regarded as objective or out there. Reality only enters our consciousness through interpretation or assimilation.

Central to the practice of information control is that of censorship through which certain ideas and information items are suppressed and withheld from the public domain. This has occurred through institutions such as library and information services and the mass media. An interesting observation regarding information control is that inasmuch as no society lacks it, so too can no ruling group successfully control information. As Merrett (1982:3) notes, ultimately no state can control either 'thought or writing' absolutely. Despite vigorous efforts at repression or co-option, resistance or expression cannot be quelled. An interesting consequence of information control has been the ever-increasing creativity of left-wing, progressive writers.

One of the aims of censorship is to deny people access to information which is not in keeping with or which opposes and undermines the values and interests of the dominant political grouping. Without such information, the assumption is that disadvantaged groups will remain relatively uninformed. A further aim is to control and restrict the expression of grievances in the hope that suppression of these will impose an atmosphere of normality and neutralize resistance.

The control of information and communication flow is an historical feature of South African society. As Merrett explains (1982:4), censorship has become

'an integral part of South African society ... Apartheid is based on repression and censorship is a vital $\operatorname{cog}$ in that system, using information and thought control to stifle healthy doubt, questioning and cynicism'.

The historical Publications and Internal Security Acts were but two measures used to control information flow in our society. However censorship must be viewed not only in relation to the banning of information, organizations and persons, it must be understood in the South African context in its entirety. As Merrett (1990) points out apartheid itself is a form of censorship which is mirrored at various levels throughout the society - its education system, security legislation, state secrecy, etc.

Naidoo (1985) notes that censorship is associated with a system of misinformation and disinformation. We are made to see the world through the eyes of dominant groupings and to assume these views as normal. Clearly Gramsci's argument that we do not only possess a false consciousness, that as individuals we articulate with realities in ways which give rise to particular interpretations of those realities, is valid. However, he also argues that those in control of the means of communication are in positions of power in being able to assert particular views as valid and more appealing than others (Buci-Glucksman, 1980:255; Gramsci, 1985:387).

\section{Information, education and development}

Based on an understanding of the socio-political nature of information, the following section attempts to draw the links between information, education and development. Whereas the previous argument sketched the way in which information can be used to reinforce dominant power relations, the following discussion explores the role which information and the information sector play or can play in a context of development in transforming power relations.

The Translis Coalition (1993:2) (in a second draft of their National Library and Information Services Policy document) argues that 'information is a valuable, strategic resource and that its availability enables citizens to participate in decisionmaking processes' thus allowing them to shape their environments. They further argue that there is a direct relationship between information and power and that within this context of power struggles, information is a 'commodity which carries ideas and is used to promote and advance ideologies'. This view, they say, marks a break from the traditional view of the neutrality of information and the various channels through which it is transmitted.

The views expressed by the Translis Coalition (1993:2) mark a conceptual shift in understandings of information including its centrality to and pivotal role in developmental contexts. Acknowledging this role, the Reconstruction and Development Programme (RDP) calls for a 'democratic information programme' which can facilitate the free flow of information so that people and government are equipped to take informed decisions (African National Congress, 1994a: 133). The RDP's commitment to 'open debate and transparency in government and society ... (as) ... crucial elements of reconstruction and development' as well as broadening of 
the Freedom of Information Act, is still to be tested in the process of transformation. However, it signals a significant break from the Apartheid regime's practices of controlling information flow for the purposes of maintaining its undemocratic status quo.

The notion of the integral relation between information and development is implicit in the paradigm shift in the information science field. The knowledge-power and informationdevelopment concepts are premised on the notion of the situationality of information and recognize the value of appropriate information in a system. The RDP's notion of an informed citizenry which proposes that people have to be informed to participate in decision-making processes, is linked to that of empowerment or the need to empower people through their access to appropriate information. As the Programme states, 'development is not about the delivery of goods to a passive citizenry. It is about active involvement and growing empowerment' (African National Congress, 1994a:5). Mchombu (1982:241) writes that:

- information work in developing countries differs markedly from that in developed countries; and

- information workers must play an active role in the process of socio-economic development.

These positions are not only pertinent to the developing world. Kempson (1986), in a British context, similarly argues the need for information agencies which will meet the needs of its citizenry. She argues that information services should be provided to help people both to participate in the running of society and to take a more equal share of the benefits of the development of society and contends that the AngloAmerican model of library and information services is not necessarily equipped to meet this essential requirement (1986:186).

In the South African setting, Barnard (1994:1) writes that the country has a long history of building and creating internal and external linkages and obstacles preventing a free flow of information. He argues that 'development depends on information' and that if

'the people of Southern Africa are to play a constructive role in accelerating and sustaining development, they need development information in a language they can understand and in a form which they can relate to their own situation'.

To understand how information can support and enhance development, the nature of development underway in South Africa will be briefly considered. The RDP framework proposes that development ought to be an integrated process (African National Congress, 1994a:6). In its consideration of a wide-range of developmental initiatives underway at any given point, it adopts a holistic approach suggesting that communities must be developed on all levels and not only in certain areas at the expense of others. For example, nutrition, electrification and housing projects are regarded as directly related to improved schooling through nurturing the student for the educational environment and providing the conditions for a culture of learning which extends beyond the classroom.
In this way too, the integration of education and training are proposed within the framework of life-long learning.

The RDP and ANC Education Policy Framework Document argue for the integration of education and training on the basis that effective human resource development has to engender a culture of and opportunity for life-long learning (African National Congress, 1994a; 1994b). This basic framework breaks with the traditional view of education being acquired only in formal institutions and seeks to accredit learning and skills 'which people have acquired through experience and informal training' (African National Congress, 1994b:10). With respect to developing a national learning system, the document states that:

'education and training have a crucial role to play in contributing to social and economic development through empowering individuals to actively participate in all aspects of society, as citizens in the democratic process, and in the economy' (African National Congress, 1994b:15).

The vision of providing quality life-long learning to all South African citizens which will be learner-centred is premised on resource-based and interactive learning approaches and marks a shift from the traditional methodology of rotelearning. This approach echoes the learner-centred approach adopted by many education-based NGOs. It is also in keeping with the situational view of information and its relation to knowledge.

An educational approach which encourages critical thinking and which draws on the skills and experiences of learners, necessarily takes cognisance of their knowledge-bases. Given the information-knowledge framework, it can be argued that information and information skills are critically important to a learner-centred pedagogy. The National Education Policy Investigation Library and Information Services (NEPI LIS) Report (1992:60) argues for an integration of information servicing with education, drawing on the example of Sweden which has high achievement levels to show that independent learning requires a wide-ranging base of learning resources.

The argument for the integration of the education and information spheres is thus premised on the belief that information is a key component in the learning process and that it is packaged not only in hard copy resources but is embedded in the very context in which people learn. As has been discussed earlier, information is part of our internal and external realities. It is mediated in a number of ways and by a number of agents. We are both subjects in our realities and agents involved in the process of interpreting our realities and producing meaning from our particular contexts. Within this framework, the role of facilitator or educator assumes major significance in mediating information in ways that allow learners the space to learn and to produce meaning.

\section{Conclusion}

In addressing the need for a conceptual understanding of information, this article has noted the situationality of information and argued that information assumes value in 
relation to a need. By drawing on the works of Althusser and Gramsci, the relationship between information and ideology has been explored. In accordance with this view, the role assumed by information institutions, including libraries, in reproducing dominant relations of power in a society has been referred to. The role played by individuals within this institutional context has also been noted with an argument made for the co-existence of multiple realities and the role individuals can play in transforming their realities. Thus people who operate within institutions and organizations are seen as key agents of change.

This article has also provided, by way of historical reflection on South African society, an argument in support of the integration of information, education and developmental work as an imperative for the realization of life-long and resource-based learning.

\section{References}

AFRICAN NATIONAL CONGRESS. 1994a. The reconstruction and development programme: a policy framework. Johannesburg: Umanyano Publications.

AFRICAN NATIONAL CONGRESS. 1994b. A policy framework for education and training. Braamfontein: African National Congress.

ALTHUSSER, L. 1972. Lenin and philosophy and other essays. New York: Monthly Review Press.

BARNARD, D. 1994. Southern Africa: the dawn of a new era. Prodder newsletter, 6(2):1-3.

BELKIN, N.J. 1977. A concept of information for information science. (PhD thesis). London: University of London.

BROOKES, B.C. 1975. The fundamental problem of information science. In Horshell, V. ed. Informatics 2. London: Aslib.

BUCI-GLUCKSMAN, C.1980. Gramsci and the state. London: Lawrence \& Wishart.

CHILDERS, T. \& POST, J. 1975. The information poor in America. Metuchen, N.J.: Scarecrow Press.

CONTEMPORARY CULTURAL STUDIES UNIT. 1988. Culture and the media: how we are made to see. Durban: University of Natal.

DERVIN, B. 1977. Useful theory for librarianship: communication not information. Drexel library quarterly, 13(3):16-32.

DERVIN, B. \& NILAN, M. 1986. Information needs and uses. Annual review of information science and technology, 21:3-33.

FAIRTHORNE, R. 1967. Morphology of information flow. Journal of the Association of Computing Machinery, 14(4):710-719.

GRAMSCI, A. 1977. Selections from prison notebooks. Edited by Q. Hoare \& G. Nowell-Smith. London: Lawrence \& Wishart.

GRAMSCI, A.1985. Selections from cultural writings. Edited by D. Forgacs \& G. Nowell-Smith. London: Lawrence \& Wishart.

HARRIS, M. 1986. State, class and cultural reproduction. Advances in librarianship, 14:211-255.

JANSEN, J. 1991. Knowledge and power in South Africa: critical perspectives across disciplines. Braamfontein: Skotaville.

KARELSE, C-M. 1995. Alternative models of information provision with special reference to the International Research and Information Group and the Education Resource and Information Project. (MBibl thesis). Cape Town: University of Cape Town. (Unpublished)
KARLSSON, J. 1994. An evaluation of the Natal Resource Centre Forums definition of a resource centre. (MInf thesis). Pietermaritzburg: University of Natal. (Unpublished).

KEMPSON, E. 1986. Information for self-reliance and selfdetermination: the role of community information services. IFLA journal, 12(3):182-191.

KING, D. \& PALMOUR, V. 1980. How needs are generated: what we have found out about them. Aslib IIS LA joint conference proceedings. London: Library Association: 68-90.

LEE, R. 1994. From projects to advocacy: NGOs in search of greater impact. Development and democracy, 7:34-43.

MATTELART, A. 1980. Mass media, ideologies and the revolutionary movement. Brighton: Harvester Press.

MCHOMBU, K. 1982. On the librarianship of poverty. Libri, 32(3): 241-250.

MERRETT, C. 1982. Political censorship in South Africa: aims and consequences. Reality, 21:3-6.

MERRETT, C. 1990. State censorship, research in the human sciences and library resources in South Africa. In Mouton, J. \& Joubert, D. eds. Knowledge and method in the human sciences. Pretoria: Human Sciences Research Council: 215-238.

MERRETT, C. 1995. Hegemony, libraries and librarians in South Africa. Paper presented at the second national LIWO Conference, Pietermaritzburg, 20-21 July 1995. (Unpublished).

MILES, I. 1990. Mapping and measuring the information economy. Library and information research report 77. Cambridge: Cambridge University Press.

MOUFFE, 1981. Hegemony and the integral state in Gramsci: towards a new concept of politics. In Bridges, G. \& Brunt, R. eds Silver linings. London: Lawrence \& Wishart: 167-187.

MYBURGH, T. 1986. Good or bad journalism ... Let the public be the judge. Communicare, 16(1):63-64.

NAIDOO, B. 1985. Censoring reality: an examination of books on South Africa. London: British Defence and Aid Fund for Southern Africa.

NATIONAL EDUCATION POLICY INVESTIGATION. 1992. Library and information services; report of the NEPI Library and Information Services Resaerch Group. Cape Town: Oxford University Press/National Education Co-ordinating Committee.

SIMON, R. 1982. Gramsci's political thought. London: Lawrence \& Wishart.

SMITH, J.G. An operational concept of information for information science. South African journal of librarianship, and information science, 50(2):71-78.

STILWELL, C. 1992. The resource centre forums: democratic and alternative information networks for South Africa. International information and library review, 24:213-220.

THERBORN, G. 1980. The ideology of power and the power of ideology. London: verso.

TRANSLIS COALITION. Working Group 1. 1993. National library and information services policy: a discussion paper of the Translis Coalition, 2nd draft document. Cape Town: The Coalition. (Unpublished).

WYLEY, C. 1990. Information, ideology and power in South Africa: the challenge facing librarians. Innovation, 1:4-17.

YOVITS, M. \& WHITMORE, B. 1973. A generalised conceptual development for the analysis and flow of information science, Journal of the American Society for Information Science, 24(3):221-231. 